\title{
Evidence-Based Prevention for Adolescent Substance Use
}

Erin Harrop, MSWa, Richard F. Catalano, PhD ${ }^{\mathrm{b}, *}$

\section{KEYWORDS}

- Prevention • Adolescent substance use $\bullet$ Young adult substance use $\bullet$ Risk factors

- Protective factors • Prevention science

\section{KEY POINTS}

- In recent decades, prevention science has emerged as a unique field with growing empirical evidence of effectiveness.

- Prevention science is based on the identification of predictors, risk and protective factors, for problem behaviors that have been found in individual, peer, family, school, and community domains.

- There is a robust evidence base for prevention programs and policies that address these identified predictors.

- Effective prevention programs can be delivered in school, family, and community settings, and they include such things as school curricula for the promotion of social and emotional competence, parenting programs, mentoring programs, normative change campaigns, and policy development.

- The challenge now is to mobilize across disciplines and communities to advance the policies, programs, funding, and workforce preparation needed to use prevention science to promote behavioral health and prevent behavioral health problems among all young people, including those at greatest disadvantage or risk, from birth through age 24 .

Adolescence is increasingly being recognized as a pivotal developmental period with defining characteristics and functions. ${ }^{1}$ Further, during the transition from adolescence to young or emerging adulthood, there are more biological, psychological, and social changes occurring than in any other stage of life, except infancy. ${ }^{2}$ During this time,

Conflict of Interest: E. Harrop has no conflicts of interest to declare. R.F. Catalano is on the board of Channing Bete Company, distributor of Guiding Good Choices and Supporting School Success, a component of the Raising Healthy Children program, 2 of the 22 programs referred to in this report.

a University of Washington School of Social Work, Seattle, WA 98026, USA; ${ }^{\text {b }}$ Social Development Research Group, University of Washington School of Social Work, 9725 Third Avenue Northeast, Suite \#401, Seattle, WA 98115, USA

* Corresponding author.

E-mail address: catalano@myuw.net 
adolescents are charged with many tasks that usher them into a period of adulthood, marked by greater independence. These developmental tasks include gaining skills to perform adult roles, separating from parents, achieving greater autonomy from adults, building social connections with peers, developing a positive body image, managing their emerging sexuality, and cultivating a more robust sense of identity. ${ }^{2,3}$

However, this period is not only marked by greater autonomy and growing responsibilities, but it is also marked by increasing experimental behaviors, through which adolescents explore the world. Neural changes in the brain during adolescence facilitate exploration and risk taking, while the cognitive functions of the brain are not yet fully developed, decreasing cognitive decision making, feelings of inhibition, and worry about the future, and increasing emotional-based decisions. ${ }^{4}$ The benefits of this unique neural developmental pattern characteristic of adolescence include rapidly increasing knowledge about the world through a variety of new experiences and a heightened neural reward system. However, this period is also marked by greater vulnerability, as adolescents can be exposed to more potentially harmful situations as a result of their experimentation and exploration. A core challenge in adolescent and young adult health promotion is that "problem behaviors" related to experimentation are a normal part of adolescent development, yet they carry with them inherent threats to health. ${ }^{5}$ These threats to health have severe consequences, including substance use problems, violence, vehicular accidents, risky sexual practices, self-harm, and even death. In fact, most adolescent and young adult deaths that occur globally are related to problem behaviors. ${ }^{6}$ Laurence Steinberg, psychologist and expert on adolescent development, summarizes this unique developmental period in the following way:

Brain science explains... why adolescence is a vulnerable period... There is a time lag between the activation of brain systems that excite our emotions and impulses and the maturation of brain systems that allow us to check these feelings and urgings-it's like driving a car with a sensitive gas pedal and bad brakes. When our capacity for self-regulation isn't strong enough to rein in our arousal, problems are more likely to result-problems such as depression, substance abuse, obesity, aggression, and other risky and reckless behavior. ${ }^{7(p 15)}$

Due to the significant consequences of adolescent problem behaviors, researchers in the past 4 decades have increasingly focused on approaches to ameliorate these behaviors in hopes of improving adolescent health outcomes and mitigating mortality rates. Although many early prevention programs had disappointing success rates (and at times iatrogenic effects), programs in the past 3 decades have achieved more promising and effective outcomes. ${ }^{8-12}$ This article specifically addresses the evidence base for prevention programs targeted at reducing substance use behaviors in adolescence and emerging adulthood. The article begins with a brief description of prevention science, followed by descriptions of key risk and protective factors specific to the adolescent and emerging adult periods. Following this, an overview of effective prevention programs and policies is described, including a brief presentation of prevention programs for adolescents and young adults with strong evidence of effectiveness. The article closes with an articulation of the challenges and opportunities currently emerging in the field.

\section{THE SCIENCE OF PREVENTING PROBLEMATIC BEHAVIORS}

Prevention science had been created as a field by incorporating and organizing findings from research on life-course development, community epidemiology, and 
preventive intervention trials. ${ }^{13}$ Prevention science is based on the premise that empirically verifiable precursors, often called risk and protective factors, affect the probability of later problems. Risk factors precede specific problematic health behaviors, and contribute to the likelihood of poor health outcomes. Similarly, protective factors precede certain health behaviors, and contribute to the likelihood of better health outcomes either directly or by reducing the effects of risk factors. ${ }^{14,15}$

Risk and protective factors exist across the life course, and occur in multiple socialization domains, including peer factors (eg, friends who use drugs), family factors (eg, family conflict), school factors (eg, academic performance), and community factors (eg, poverty, community laws and norms), ${ }^{16}$ as well as individual factors (eg, early aggression and temperament). Thus, risk and protective factors span individual to structural factors, with multiple influences across socialization domains affecting the health outcomes of adolescents. The exposure to multiple risk factors appears to be cumulative. The more risk factors an adolescent has, the more likely a problematic health outcome is to occur. ${ }^{14,17}$ However, risk factors also can be moderated or mediated by the presence of protective factors, which increase the likelihood of healthy development. ${ }^{14,15}$ Additionally, risk and protective factors often influence more than one problem behavior. ${ }^{16}$ Because risk and protective factors tend to cluster in the individual and risk/protective factors affect multiple problem behaviors, interventions that seek to change a single or a cluster of risk or protective factors may demonstrate effects on multiple outcomes because they are all predicted by the risk/protective factors addressed. ${ }^{16}$ Thus, although this article focuses primarily on the prevention of substance use behaviors, many of the programs discussed have multiple beneficial outcomes, including reducing violence, enhancing mental health, and decreasing unwanted pregnancies.

Prevention programs are typically viewed as occurring on a spectrum from health promotion to indicated prevention (Fig. 1). ${ }^{13}$ Substance use prevention programs can be aimed at a range of goals, from preventing initiation of substance use through preventing the development of substance use-related problems or substance use

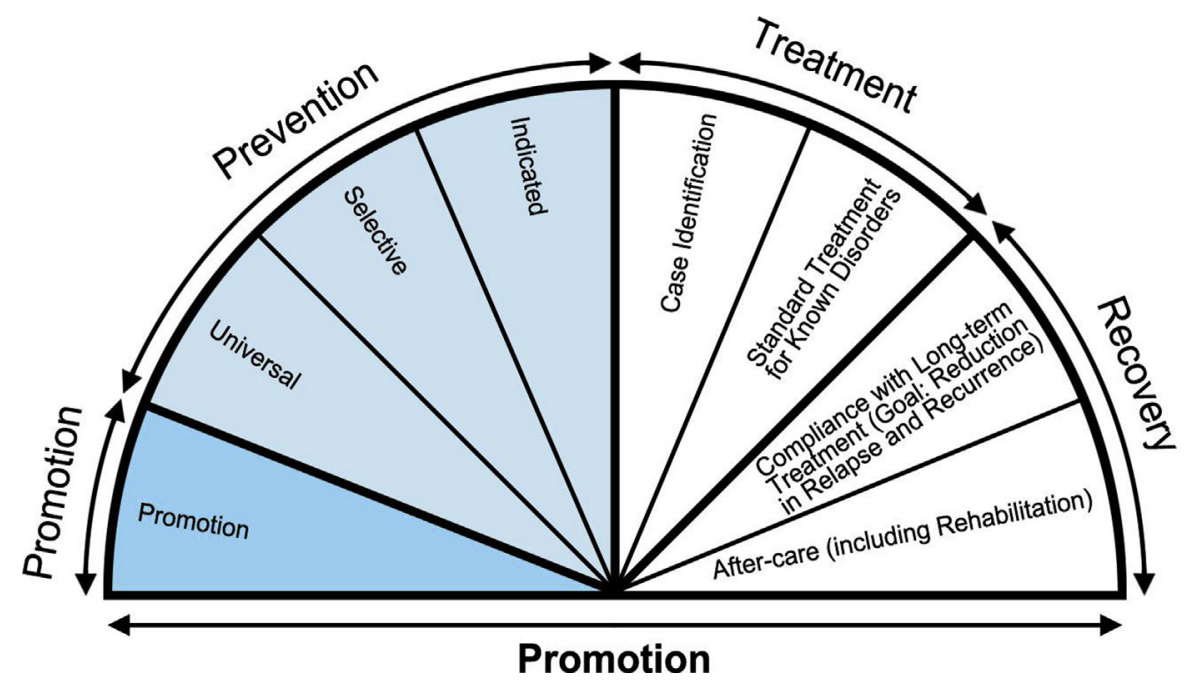

Fig. 1. Intervention spectrum. (From O'Connell ME, Boat T, Warner, KE. Preventing mental, emotional, and behavioral disorders among young people: progress and possibilities. Washington, DC: National Academies Press, 2009; with permission.) 
dependence. Health promotion efforts involve the promotion of healthy behaviors, and do not explicitly target the reduction of problem behaviors. Prevention programs aim to reduce problem behaviors and are divided into 3 categories addressing different levels of risk within a population: universal, selective, and indicated prevention programs. ${ }^{16}$ Universal prevention programs target reducing substance use in an entire population without regard to risk. Universal programs are frequently used because research has found that most cases of a complex disorder come from the large proportion of the population that is at low or moderate risk (genetic or environmental) for that disorder, and only a minority of cases occur in the small proportion of the population that is high risk. In a study of mortality from coronary disease, Geoffrey Rose coined the term prevention paradox to describe this phenomenon and demonstrated that a large number of people at a small risk may give rise to more cases of disease than the small number who are at a high risk. ${ }^{18}$ Policy-level interventions, such as drinking-age laws and graduated licensing for drivers, are examples of universal prevention policies. Selective programs are targeted at populations that show increased levels of risk, such as programs delivered in neighborhoods with high levels of crime. Finally, indicated programs target individuals who have already begun to use, but have yet to show symptoms of abuse or dependence, such as adolescents who have initiated substance use but have not yet developed regular use associated with negative consequences.

\section{RISK FACTORS FOR SUBSTANCE USE}

In the past 4 decades, much work has been done to identify risk and protective factors for adolescent substance use and other problems. ${ }^{19}$ Risk factors have been shown to be consistent predictors across groups, including gender, ethnicity, community, and country. ${ }^{20}$ Risk factors are grouped by socialization domain, and organized into community factors, school factors, family factors, and individual/peer factors. Table 1 summarizes risk factors for adolescent substance use and other problems and provides information from a recent review of risk factors for young adult substance use. ${ }^{21}$ We first provide an overview of risk factors associated with adolescent substance use and other problems, followed by a brief summary of risk factors specific to young adult substance use.

\section{Risk Factors for Substance Use in Adolescence}

Characteristics of communities can increase the likelihood that adolescents within those communities will use substances. When a community has laws and norms that are favorable to substance use, such as low enforcement of drinking ages or frequent community events featuring alcohol, youths in these communities are more likely to use substances. ${ }^{15}$ Another key factor is availability. Availability of substances varies from community to community, with some communities having greater availability (eg, more liquor or marijuana stores). Communities with higher availability have increased rates of youth substance use. ${ }^{22}$ It has also been found that perception of availability is also an important factor. If youth merely perceive that drugs and alcohol are more available, this perception (however inaccurate) is also associated with higher rates of youth drug use. ${ }^{23}$ Perhaps influencing adolescents' perception of substance availability or acceptability, media portrayals of substance use in communities (ranging from alcohol advertisements to movies featuring substance use) have also been linked to substance abuse and earlier initiation of substance use. ${ }^{24}$

Other community factors that are less directly linked to substance use can also impact youth substance use. For example, communities with higher rates of mobility 
have been linked with higher rates of drug problems. ${ }^{25}$ Extreme economic deprivation also can be a risk factor for later substance abuse problems, particularly when children in those communities experience both poverty and early behavioral problems. ${ }^{25}$ Additionally, adolescents living in neighborhoods lacking organization, with less surveillance of public places, and fewer strong social institutions, also show increased rates of substance use. ${ }^{26}$

In the school domain, academic failure, as early as mid-elementary school, has been linked with increased risk of substance use and substance-related problems in adolescence. ${ }^{27}$ Low commitment to school or having low expectations for achievement or finding school is unrewarding, are all associated with increased substance use. ${ }^{28}$

In the family domain, parental attitudes toward drug use are similarly predictive of later adolescent use. Adolescents are more likely to engage in substance use behavior when their parents have favorable or approving attitudes toward drug and alcohol use. ${ }^{29,30}$ Parental history of drug or alcohol abuse also predicts adolescent substance use, and increases the likelihood that a teen will progress from experimentation with substances to more significant substance-related problems. ${ }^{31,32}$ Also, coming from a family with a substance-abusing parent has been linked to dependence for a wide range of substances, with twin studies in which children separated at birth from substance-using parents show increased risk of problems, suggesting that there may be an underlying heritable, possibly genetic, component to substance use. ${ }^{33-36}$ Family management problems, including poor supervision and monitoring, lack of clear behavioral expectations, and inconsistent or harsh punishment are associated with increased risk of adolescent substance abuse problems. ${ }^{29,37,38}$ Additionally, adolescents raised in families with high levels of conflict are also more likely to use substances and later develop substance use problems. ${ }^{39}$

In the individual and peer domain, several constitutional factors have emerged as consistent predictors of later substance use. Individuals characterized as sensation seekers or risk takers, having low harm avoidance and higher impulsivity, are more likely to engage in substance use behaviors. ${ }^{15,40}$ Similarly, adolescents who display more frequent and higher levels of childhood aggressive behavior, and antisocial behavior in early adolescence, are also more likely to engage in substance use behaviors. ${ }^{22,41-43}$ Not surprisingly, having friends who engage in antisocial behavior, and being friends with peers who use substances, also predicts later substance use. ${ }^{44,45}$ Rebelliousness has also been linked with regular cigarette and alcohol use, in addition to current use of marijuana. ${ }^{46}$ An adolescent's own attitude toward alcohol and other drugs is also predictive of later drug use, with adolescents who view substance use more favorably being more likely to initiate substance use. ${ }^{47}$ As in the case of many risky behaviors, the earlier an adolescent initiates use of substances, the more likely he or she is to develop substance abuse problems later in life. ${ }^{48}$

As can be seen in Table 1, risk factors for adolescent substance abuse also predict other adolescent problems. This implies that interventions that address risk factors for substance abuse will likely affect multiple problems. ${ }^{19}$ In sum, "This commonality also suggests that preventive interventions that address precursors of multiple problems are an efficient approach."13(p1654)

\section{Risk Factors for Substance Use in Emerging Adulthood}

Emerging adulthood (usually defined as the period from age 18 to age 25) is an important time in life because it sets the stage for later adult development. ${ }^{49-52}$ Many researchers ${ }^{52-55}$ have identified this stage as another key developmental time period characterized by rapid transitions in social context. This developmental period is 


\section{Table 1}

Risk factors for adolescent and young adult problem behaviors

\begin{tabular}{|c|c|c|c|c|c|c|c|}
\hline Risk Factors & $\begin{array}{l}\text { Adolescent } \\
\text { Substance Use }\end{array}$ & Delinquency & $\begin{array}{l}\text { Teen } \\
\text { Pregnancy }\end{array}$ & $\begin{array}{l}\text { School } \\
\text { Dropout }\end{array}$ & Violence & $\begin{array}{l}\text { Depression } \\
\text { and Anxiety }\end{array}$ & $\begin{array}{l}\text { Young Adult } \\
\text { Substance Use }\end{array}$ \\
\hline Availability of drugs & $\nu$ & - & - & - & V & - & $\nu$ \\
\hline $\begin{array}{l}\text { Community laws and norms favorable to drug use, } \\
\text { firearms, and crime }\end{array}$ & $\boldsymbol{V}$ & レ & - & - & レ & - & $\boldsymbol{V}$ \\
\hline Media portrayal of violence & $\boldsymbol{\nu}$ & - & - & - & レ & - & - \\
\hline Extreme economic deprivation & $\boldsymbol{\nu}$ & $\boldsymbol{\nu}$ & $\boldsymbol{\nu}$ & $\boldsymbol{\nu}$ & $\boldsymbol{\nu}$ & - & - \\
\hline Transitions and mobility & レ & レ & - & レ & - & $\boldsymbol{\nu}$ & - \\
\hline \multicolumn{8}{|l|}{ School } \\
\hline Academic failure beginning in late elementary school & $\boldsymbol{\nu}$ & レ & レ & レ & レ & $\boldsymbol{\nu}$ & $\nu$ \\
\hline \multicolumn{8}{|l|}{ Family } \\
\hline Family history of the problem behavior & $\boldsymbol{\nu}$ & $\boldsymbol{\nu}$ & $\boldsymbol{\nu}$ & $\boldsymbol{\nu}$ & $\boldsymbol{\nu}$ & $\boldsymbol{\nu}$ & $\boldsymbol{\nu}$ \\
\hline
\end{tabular}


Individual/Peer

\begin{tabular}{|c|c|c|c|c|c|c|c|}
\hline Early and persistent antisocial behavior & $\boldsymbol{\nu}$ & $\boldsymbol{\nu}$ & $\boldsymbol{レ}$ & $\boldsymbol{\nu}$ & $\boldsymbol{\nu}$ & $\boldsymbol{\nu}$ & $\boldsymbol{\nu}$ \\
\hline Alienation and rebelliousness & $\boldsymbol{\nu}$ & $\boldsymbol{\nu}$ & - & $\boldsymbol{\nu}$ & - & - & - \\
\hline Early initiation of the problem behavior & レ & レ & レ & レ & $\boldsymbol{V}$ & - & $\nu$ \\
\hline Friends who engage in the problem behavior & レ & レ & レ & $\boldsymbol{\nu}$ & $\boldsymbol{\nu}$ & - & $\boldsymbol{\nu}$ \\
\hline Constitutional factors & $\nu$ & $\boldsymbol{\nu}$ & - & - & レ & レ & $\boldsymbol{\nu}$ \\
\hline Internalizing & - & - & - & - & - & - & $\boldsymbol{\nu}$ \\
\hline Not living with parents or spouse & - & - & - & - & - & - & $\boldsymbol{\nu}$ \\
\hline Being unmarried & - & - & - & - & - & - & - \\
\hline College attendance & - & - & - & - & - & - & $\nu$ \\
\hline Being unemployed & - & - & - & - & - & - & $\nu$ \\
\hline
\end{tabular}

Adapted from Catalano RF, Haggerty KP, Hawkins JD, et al. Prevention of substance use and substance use disorders: the role of risk and protective factors. In: Kaminer Y, Winters KC, editors. Clinical manual of adolescent substance abuse treatment. Washington, DC: American Psychiatric Publishing; 2011. p. 30-1; with permission. 
characterized by new social contexts that involve greater freedom and less social control than experienced during adolescence. Along with changing societal roles, there is a simultaneous weakening of societal safety net supports. ${ }^{56}$ Among the transitions facing young adults, many have significant developmental impacts: they may leave home, exit the compulsory educational system, begin college, enter the workforce, and form families. ${ }^{56}$ Navigating these transitions requires skills and resources that can be compromised by substance use.

Concurrent with this new found independence is an increase in rates of substance use and abuse, sexual risk behaviors, and the beginning of a decline from the peak of criminal involvement. Longitudinal data from the Monitoring the Future survey indicates that rates of heavy alcohol, marijuana, and daily smoking peak in the mid-20s and decline slowly thereafter. ${ }^{56,57}$ Rates of abuse and dependence on alcohol and illicit drugs follow a similar trend. ${ }^{3}$ Additionally, rates of driving under the influence peak during young adult years. ${ }^{57}$ Increasing transitions that offer more freedom and less control, and the concomitant increase in substance use and misuse suggests that young adults may need additional supports. Further, there is a substantial portion of the population whose substance use persists or even escalates beyond the mid20s. ${ }^{58-61}$ Substance misuse, if sustained, progresses to dependence and contributes to failure to successfully adopt adult roles and responsibilities, as well as the emergence of other mental health problems. ${ }^{62-66}$ Thus, understanding the risk and protective factors specific to young adults is critical as we seek to reduce the impact of substance-related problems.

Many predictors of young adult substance abuse are those already described during childhood and adolescence that persist as predictors; however, many are unique to the young adult period (see Table 1). Stone and colleagues ${ }^{21}$ document the predictors of young adult substance use. During young adulthood, in the community domain, the availability of drugs, community laws and norms favorable to substance use, and lower income and parental education increased the risk for young adult substance use. Extreme economic deprivation during childhood also predicted young adult use. In the family domain, family history of substance use, family management problems, family conflict, and favorable parental attitudes toward substance use from childhood and adolescence predicted young adult substance abuse. For example, White and colleagues' study of risk factors in emerging adulthood found that good parental monitoring of behavior that occurred in high school continued to decrease risk for alcohol and marijuana use into young adulthood. This research suggests that not only can preventive family-based efforts produce positive outcomes for adolescents who are still in the home, but also these preventive interventions' effects have been found to persist into young adulthood. ${ }^{67}$ Efforts to involve parents to assist adolescents in the transition to more independent living have also shown effects. ${ }^{68}$ Family conflict during young adulthood also predicted young adult substance use. School failure at any age (during childhood, adolescence, or in young adulthood) is linked with increased substance use in young adulthood. However, lack of commitment to school specifically emerged as a predictor of young adult substance use only during adolescence. In the individual domain, antisocial behavior and favorable attitudes toward substance use at any age predicted young adult substance abuse. Constitutional factors and early initiation of substance use were predictors of young adult substance use from the childhood period only. Having friends who use substances (during adolescence and young adulthood) was predictive of young adult substance abuse.

In addition to these risk factors, there are several specific risk factors that have emerged as uniquely important in emerging adulthood. Living situation often changes when a young person reaches emerging adulthood. Although some young adults 
continue to live at home with parents while beginning college or starting their employment journey, many young people live away from their parents for the first time, either on a college campus or in housing on their own or with peers. Living situation has been found to be closely connected to substance use, with young adults living away from home experiencing significantly more substance use than young adults who continue to live with their parents. ${ }^{69}$ This finding remains significant regardless of college attendance. ${ }^{69}$

Interestingly, although grades during high school are related to decreased rates of substance use in adolescence, these same high school grades are related to increased risk for substance use in emerging adulthood. ${ }^{28,67}$ This could be because those with higher grades in high school are more likely to attend college and that aspects of the college environment encourage heavy drinking, and increase accessibility of alcohol. ${ }^{70,71}$ White and colleagues ${ }^{67}$ also found that although college attendance increased alcohol use for young adults overall, young adults attending college who still lived at home with parents experienced a smaller increase in alcohol use behaviors compared with those who did not live with their parents. Also, being unmarried ${ }^{72}$ and being unemployed during emerging adulthood are both risk factors for young adult substance abuse. Being unemployed was also associated with greater risk for developing substance use disorders. ${ }^{73,74}$

\section{PROTECTIVE FACTORS FOR SUBSTANCE USE IN ADOLESCENCE AND EMERGING ADULTHOOD}

Opportunities for prevention exist not only in programs that seek to decrease risk factors, but also in seeking to increase protective factors. Protective factors can directly lower the likelihood of substance use problems or mediate or moderate risk. During adolescence, in the community and school domains, opportunities for prosocial involvement, such as after-school clubs, youth organizations, and community events, act protectively against substance use, with adolescents experiencing less risk for substance use. ${ }^{46}$ Similarly, recognition for involvement in prosocial activities at school is also protective against substance use behaviors. ${ }^{46}$ At the family level, a similar trend emerges, where opportunities for prosocial involvement in the family, such as game nights and opportunities to help with chores, are similarly associated with fewer substance use behaviors, as is family recognition of prosocial involvement. ${ }^{46}$ Resnick and colleagues $^{75}$ found adolescents with a higher sense of attachment or connection to their families also displayed lower rates of multiple problem behaviors, including substance use, sexual initiation, violence, and suicidal behaviors; the same was true for adolescents with a higher perception of attachment to their schools. Finally, at the individual level, Beyers and colleagues ${ }^{46}$ found that higher religiosity, social skills, and healthy beliefs and clear standards were all protective factors for adolescent substance use. Healthy beliefs and clear standards were also protective for young adults. Considerably less is known about protective factors in young adulthood, as less research has explored protection for young adult substance abuse.

\section{EVIDENCE-BASED PREVENTION PROGRAMS WITH IMPACT ON SUBSTANCE USE Overview of Prevention Program Development}

According to Mrazek and Haggerty, ${ }^{76}$ prevention programs are typically developed through a series of stages in prevention science. The first stage, epidemiology studies, involves understanding the prevalence of problem behaviors or disease, along with the associated predictors of those problem behaviors or diseases. Developing theory that can explain how these predictors work together to cause negative health 
outcomes and behaviors is the next step. Once risk and protective factors have been identified, and theoretical explanations for how they work together have been established, prevention programs can be developed by constructing a logic model. Logic models should indicate which risk and protective factors will be addressed by the program, and the activities through which the intervention is expected to reduce risk and enhance protection. Promising targets for preventive interventions are those factors that predict multiple problems and/or those predictors that tend to cluster in individuals. The logic model should specify the changes expected, including short-term changes related to the intervention activities themselves (eg, improved parenting skills), intermediate-term outcomes on risk and protection (eg, reduction in family management problems and increases in family bonding), and long-term impacts on the problems targeted (eg, decreased initiation or substance misuse).

The next step is to develop the activities suggested by the logic model that may change the targeted risk and protective factors, and then conduct a pilot or feasibility trial of the intervention. After making the changes to the intervention suggested by the pilot study, efficacy trials can be developed in which the prevention intervention is tested through a controlled trial with either a quasi-experimental or experimental design. If the efficacy trial demonstrates that the prevention program has had the expected short-term, intermediate-term, and long-term impacts, an effectiveness trial should be conducted. Effectiveness trials are conducted to see if efficacious programs can still produce expected outcomes in real-world settings delivered outside of the controlled setting of the efficacy trial. This is necessary because experimental settings often fail to mimic real-world conditions, and before widespread dissemination, it is important to evaluate whether or not the prevention program continues to have positive effects in real-world settings. Finally, once effectiveness is demonstrated, diffusion trials can be conducted to address issues that arise in the implementation and dissemination of prevention programs at scale (eg, do they reach large proportions of the target population, are they delivered with fidelity to the intervention protocols, are they sustained).

\section{Key Factors in Developing and Implementing Prevention Interventions}

When designing and developing a prevention intervention, several key factors must be considered. First, target risk factors should be identified. Second, a theory of behavior change should guide the development of the intervention (eg, Social Cognitive Theory, ${ }^{77}$ the Social Development Strategy, ${ }^{78}$ the Health Belief Model ${ }^{79}$ ). Third, a prevention intervention should occur before the initiation or escalation of problem behaviors. ${ }^{80}$ Timing is essential in prevention research, as many substance use behaviors begin in early adolescence and peak in emerging adulthood, thus preventive efforts should begin before the onset of the targeted substance use behavior (initiation, regular use, abuse, and dependency). ${ }^{80}$

\section{Effective and Efficacious Prevention Programs}

There have been many reviews of efficacy trials of prevention programs. ${ }^{19}$ A relatively large number of prevention programs have demonstrated in controlled trials shortterm and long-term impacts on preventing substance use. Several lists of efficacious prevention programs have been developed by government and nongovernmental bodies (Blueprints for Healthy Youth Development ${ }^{81}$ National Registry of Evidencebased Programs and Practices, ${ }^{82}$ Office of Juvenile Justice and Delinquency Prevention, ${ }^{83}$ What Works Clearinghouse, ${ }^{84}$ Centers for Disease Control and Prevention Community Guides, ${ }^{85}$ Coalition for Evidence-Based Policy ${ }^{86}$ ). One of the most rigorous of these lists, Blueprints for Healthy Youth Development, ${ }^{81}$ has been 
developed by the Center for the Study and Prevention of Violence. We have chosen to use this list to illustrate the types of efficacious prevention programs that have been trialed and have effects on substance use. This Web-based tool keeps a record of prevention programs that have been empirically supported, and rates them according to several criteria, including impact; evaluation quality; intervention specificity regarding target population; risk and protective factors identified and intervention activities; and whether the program has training, technical assistance, and cost information. It has 3 categories of programs: Promising, Model, and Model Plus. To meet the standards of a Promising program, interventions must show positive findings in at least 1 highquality randomized controlled trial or 2 high-quality quasi-experimental trials. Promising programs must also identify the specific behavioral outcomes and associated risk factors, and be ready for dissemination with all of the necessary manuals, trainings, and other assistance needed to implement the program in a community. Model programs meet all of these criteria, but in addition have been tested in at least 2 randomized controlled trials. Finally, Model Plus programs meet all the forgoing criteria and have also been supported in an independent replication by someone who was not one of the program developers.

Table 2 shows the Blueprint programs demonstrating effectiveness at the Promising, Model, and Model Plus levels delivered in middle childhood, adolescence, and emerging adulthood, respectively. Prevention programs are typically delivered in 1 of 3 settings: school, family, and community. A brief overview of programs in these domains follows, with more complete program identification available in Table 2.

School-based programs are delivered any time from preschool (eg, Positive Action $^{87}$ ) up through postsecondary education (eg, alcohol BASICS [Brief Alcohol Screening and Intervention for College Students] education ${ }^{88}$ ). School-based programs take many forms, but effective school-based programs typically incorporate one or several of the following elements: teacher instructional and classroom management skills; curricula that teaches social, emotional, and cognitive skills; and tutoring. ${ }^{19}$ School-based programs can focus both on risk factors, such as academic failure, and protective factors, such as increasing student bonding or connectedness to the school, or increasing the availability of prosocial opportunities at the school. Life Skills Training ${ }^{89}$ and Positive Action ${ }^{87}$ are examples of Model Plus and Model schoolbased prevention programs.

Family-based programs throughout childhood and adolescence have been shown to reduce substance use in adolescence. Universal parenting programs focus on parenting skills during childhood and adolescence, including aspects such as establishing clear standards for behavior, family management skills, strategies for dealing with anger, and creating prosocial opportunities for children. Guiding Good Choices, ${ }^{90,91}$ Familias Unidas, ${ }^{92}$ and Strengthening Families $10-14^{93,94}$ are examples of family-based programs that have demonstrated strong empirical findings. Some parenting programs work with families having more difficulties. Functional Family Therapy (FFT) is an indicated prevention program that works with families that have a delinquent adolescent at risk for institutionalization. Like universal parenting programs, FFT works on family communication and supportiveness and behavior management, but in addition works on decreasing intense negativity and dysfunctional patterns of family behavior. ${ }^{95}$

Community programs typically use prevention coalitions to implement communitylevel interventions and pursue policy changes that support reductions in substance use. Community-level interventions include such things as normative change campaigns $^{96}$ (eg, billboards stating the percentages of adolescents who do not use alcohol or drugs) and community mentoring programs, such as Big Brothers Big 
Table 2

Blueprints substance use prevention programs for adolescents and young adults

Benefits Minus

Cost Per

Program

Description

Rating

Impact

Individual

\begin{tabular}{|c|c|c|c|c|}
\hline $\begin{array}{l}\text { Raising Healthy } \\
\text { Children }\end{array}$ & $\begin{array}{l}\text { Universal prevention for ages 5-18 (family and school setting). } \\
\text { Targeting classroom teachers, parents, and students to } \\
\text { promote opportunities, skills, and recognition. Parent } \\
\text { training and teacher training provided, focusing on } \\
\text { classroom management. }\end{array}$ & Promising & $\begin{array}{l}\text { Academic performance, alcohol, } \\
\text { antisocial aggressive behavior, } \\
\text { illicit drug use, prosocial with } \\
\text { peers. }\end{array}$ & $\mathrm{N} / \mathrm{A}$ \\
\hline EFFEKT & $\begin{array}{l}\text { Universal prevention for ages } 12-14 \text { (family, school, and } \\
\text { community setting). Targets parental attitudes about child } \\
\text { alcohol use through information disseminated at meetings, } \\
\text { through parent letters, and advertisement of healthy } \\
\text { activities for children. }\end{array}$ & Promising & $\begin{array}{l}\text { Alcohol, delinquency and criminal } \\
\text { behavior. }\end{array}$ & N/A \\
\hline $\begin{array}{l}\text { Positive Family } \\
\text { Support-Family } \\
\text { Check-Up }\end{array}$ & $\begin{array}{l}\text { Universal, selective, and indicated prevention for ages 12-14 } \\
\text { (family, school setting). Six-week school curriculum } \\
\text { addressing universal prevention, creation of a Family } \\
\text { Resource Center teaching parenting behaviors and family } \\
\text { management skills, and a family checkup with a trained } \\
\text { therapist. }\end{array}$ & Promising & $\begin{array}{l}\text { Alcohol, depression, sexual risk } \\
\text { behaviors, tobacco. }\end{array}$ & $(\$ 251)$ \\
\hline Positive Action & $\begin{array}{l}\text { Universal prevention for ages } 5-14 \text { (school setting). } \\
\text { Schoolwide program that includes climate change, } \\
\text { curriculum lessons } 2-4 \text { times a week in grades } \mathrm{K}-8 \text { focused } \\
\text { on socioemotional development and reinforcement of } \\
\text { positive actions. }\end{array}$ & Model & $\begin{array}{l}\text { Academic performance, alcohol, } \\
\text { anxiety, bullying, delinquency } \\
\text { and criminal behavior, } \\
\text { depression, emotional } \\
\text { regulation, prosocial behavior, } \\
\text { illicit drug use, sexual risk } \\
\text { behaviors, tobacco, truancy, } \\
\text { school attendance, violence. }\end{array}$ & $\$ 8583$ \\
\hline
\end{tabular}


Achievement

Mentoring-

Middle School
Selective prevention for ages 12-14 (school setting); 2-y program in which teens meet in small groups and

systematically work through behavior change through feedback, incentives, and a points-based program.
Promising Academic performance, delinquency and criminal behavior, employment, illicit drug use, truancy, school attendance.

Life Skills Training Universal prevention for ages 12-18 (school setting). LST is 3-y program delivered in middle school, focusing on decision making, goal setting, anger management, stress reduction, communication, peer pressure, and consequences of drug use.

\begin{tabular}{|c|c|c|c|c|}
\hline Project Northland & $\begin{array}{l}\text { Universal prevention for ages } 12-18 \text { (school setting); } 6-y \\
\text { intervention delivered in middle and high school, involving } \\
\text { classroom curricula, peer leadership, youth-driven } \\
\text { extracurricular activities, parent involvement programs, and } \\
\text { community activism. }\end{array}$ & Promising & Alcohol. & $\$ 188$ \\
\hline $\begin{array}{l}\text { Project Toward No } \\
\text { Drug Abuse }\end{array}$ & $\begin{array}{l}\text { Universal and selective prevention for ages } 15-18 \text { (school } \\
\text { setting). Twelve } 40-\text { min sessions delivered in school over } \\
3 \text { wk focusing on communication, resource acquisition, and } \\
\text { decision-making strategies. }\end{array}$ & Model & $\begin{array}{l}\text { Alcohol, illicit drug use, tobacco, } \\
\text { violent victimization. }\end{array}$ & $\$ 431$ \\
\hline $\begin{array}{l}\text { Athletes Training } \\
\text { and Learning to } \\
\text { Avoid Steroids } \\
\text { (ATLAS) }\end{array}$ & $\begin{array}{l}\text { Universal prevention for young men ages } 15-18 \text { (school } \\
\text { setting); 14-session program delivered to male athletes in } \\
\text { high school about the dangers of steroids and other drug } \\
\text { use, strength training, and sports nutrition. }\end{array}$ & Promising & $\begin{array}{l}\text { Alcohol, illicit drug use, physical } \\
\text { health and well-being. }\end{array}$ & N/A \\
\hline $\begin{array}{l}\text { SPORT Prevention } \\
\text { Plus Wellness }\end{array}$ & $\begin{array}{l}\text { Universal prevention for ages } 15-18 \text { (school setting). Health } \\
\text { promotion program for high school adolescents to improve } \\
\text { their physical fitness, nutrition, body image, and sleep } \\
\text { habits, and avoid drug use, involving a health behavior } \\
\text { screen, a one-on-one consultation, and a take-home fitness } \\
\text { prescription. }\end{array}$ & Promising & $\begin{array}{l}\text { Alcohol, illicit drug use, physical } \\
\text { health and well-being, tobacco. }\end{array}$ & $\$ 1309$ \\
\hline
\end{tabular}

(continued on next page) 


\begin{tabular}{|c|c|c|c|c|}
\hline \multicolumn{5}{|l|}{$\begin{array}{l}\text { Table 2 } \\
\text { (continued) }\end{array}$} \\
\hline Program & Description & Rating & Impact & $\begin{array}{l}\text { Benefits Minus } \\
\text { Cost Per } \\
\text { Individual }\end{array}$ \\
\hline $\begin{array}{l}\text { Blues Program } \\
\text { (Cognitive- } \\
\text { Behavioral } \\
\text { Group } \\
\text { Depression } \\
\text { Prevention) } \\
\end{array}$ & $\begin{array}{l}\text { Selective and indicated prevention program for ages } 15-18 \\
\text { (school setting). Six, weekly 1-h groups delivered to high } \\
\text { school students with depression, focusing on cognitive } \\
\text { restructuring techniques and coping skills. }\end{array}$ & Model & Depression, illicit drug use. & $(\$ 126)$ \\
\hline $\begin{array}{l}\text { Brief Alcohol } \\
\text { Screening and } \\
\text { Intervention for } \\
\text { College } \\
\text { Students } \\
\text { (BASICS) }\end{array}$ & $\begin{array}{l}\text { Selected and indicated prevention for college students (school } \\
\text { setting). A brief, motivational, cognitive-behavioral training } \\
\text { delivered in schools as a selective and indicated prevention } \\
\text { for alcohol-use problems. This program works with high-risk } \\
\text { college students to enhance motivation to change, promote } \\
\text { healthier choices, and teaches coping skills to moderate } \\
\text { drinking behaviors. }\end{array}$ & Model & Alcohol use. & $\$ 1853$ \\
\hline $\begin{array}{l}\text { InShape } \\
\text { Prevention Plus } \\
\text { Wellness }\end{array}$ & $\begin{array}{l}\text { Universal prevention for college students (school setting). } \\
\text { Cognitive-behavioral training delivered in school, aimed at } \\
\text { improving physical, mental, and spiritual well-being } \\
\text { through positive health habits. }\end{array}$ & Promising & Alcohol use, illicit drug use. & $(\$ 359)$ \\
\hline \multicolumn{5}{|l|}{ Family programs } \\
\hline $\begin{array}{l}\text { Guiding Good } \\
\text { Choices }\end{array}$ & $\begin{array}{l}\text { Universal prevention for ages } 12-14 \text { (family, school, } \\
\text { community setting). Parenting program delivered over } 5 \\
\text { sessions, focusing on family management strategies, } \\
\text { adolescent refusal skills, coping with conflict, and prosocial } \\
\text { family involvement. }\end{array}$ & Promising & $\begin{array}{l}\text { Alcohol, delinquency and criminal } \\
\text { behavior, depression, illicit drug } \\
\text { use. }\end{array}$ & $\$ 981$ \\
\hline $\begin{array}{l}\text { Strengthening } \\
\quad \text { Families } 10-14\end{array}$ & $\begin{array}{l}\text { Universal prevention for ages 12-14 (family, community, } \\
\text { school setting). Seven-session program to enhance family } \\
\text { protection and resiliency involving parent-child skill } \\
\text { building, conflict resolution, communication, and activities } \\
\text { to increase family cohesiveness and positive involvement of } \\
\text { the child. }\end{array}$ & Promising & $\begin{array}{l}\text { Alcohol, antisocial aggressive } \\
\text { behavior, close relationships } \\
\text { with parents, illicit drug use, } \\
\text { internalizing, tobacco. }\end{array}$ & $\$ 2893$ \\
\hline
\end{tabular}


Treatment Foster Care Oregon
Indicated prevention for ages 12-18 (family setting). Intensive in-home treatment for antisocial adolescents involving supervision, clear limits/consequences, positive reinforcement, an adult mentor, and daily/weekly family support.

\begin{tabular}{|c|c|c|c|c|}
\hline $\begin{array}{l}\text { Functional Family } \\
\text { Therapy (FFT) }\end{array}$ & $\begin{array}{l}\text { Indicated prevention for ages 12-18 (family setting). FFT offers } \\
\text { short-term, intensive therapeutic family services for } 3 \text { mo, } \\
\text { focusing on supervision, discipline, and emotional support. }\end{array}$ & Model & $\begin{array}{l}\text { Delinquency and criminal } \\
\text { behavior, illicit drug use. }\end{array}$ & $\$ 26,973$ \\
\hline $\begin{array}{l}\text { Familias Unidas } \\
\text { Preventive } \\
\text { Intervention }\end{array}$ & $\begin{array}{l}\text { Selective prevention for Hispanic or Latino youth age } 12-18 \\
\text { (family setting). Helps immigrant parents build a strong } \\
\text { parent support network and learn culturally relevant } \\
\text { parenting skills. }\end{array}$ & Promising & $\begin{array}{l}\text { Externalizing, illicit drug use, } \\
\text { sexual risk behaviors. }\end{array}$ & $\mathrm{N} / \mathrm{A}$ \\
\hline $\begin{array}{l}\text { Multisystemic } \\
\text { Therapy }\end{array}$ & $\begin{array}{l}\text { Indicated prevention for ages } 12-18 \text { (family and community } \\
\text { setting). Intensive family-based and community-based } \\
\text { treatment that addresses serious antisocial behavior in } \\
\text { juvenile offenders over 3-5 mo of treatment. }\end{array}$ & Model Plus & $\begin{array}{l}\text { Close relationships with parents, } \\
\text { delinquency and criminal } \\
\text { behavior, illicit drug use, } \\
\text { internalizing, mental health, } \\
\text { prosocial behavior, violence. }\end{array}$ & $\$ 15,611$ \\
\hline \multicolumn{5}{|l|}{ Community programs } \\
\hline $\begin{array}{l}\text { PROSPER } \\
\text { (Promoting } \\
\text { School- } \\
\text { Community- } \\
\text { University } \\
\text { Partnerships to } \\
\text { Enhance } \\
\text { Resilience) }\end{array}$ & $\begin{array}{l}\text { Universal prevention for ages } 12-14 \text { (school, community } \\
\text { settings). Delivery system to foster implementation of } \\
\text { evidence-based youth and family interventions, complete } \\
\text { ongoing needs assessments, monitor implementation, and } \\
\text { evaluate outcomes. }\end{array}$ & Promising & $\begin{array}{l}\text { Alcohol, close relationships with } \\
\text { parents, delinquency and } \\
\text { criminal behavior, illicit drug } \\
\text { use, tobacco. }\end{array}$ & $\mathrm{N} / \mathrm{A}$ \\
\hline $\begin{array}{l}\text { Communities That } \\
\text { Care }\end{array}$ & $\begin{array}{l}\text { Universal prevention for infants through early adults } \\
\text { (community setting). An encompassing community } \\
\text { approach that selects and uses effective prevention } \\
\text { programs that are individually tailored to the risk and } \\
\text { protection factors unique to that community. }\end{array}$ & Promising & $\begin{array}{l}\text { Alcohol use, delinquency and } \\
\text { criminal behavior, tobacco use, } \\
\text { and violence. }\end{array}$ & $\$ 1188$ \\
\hline
\end{tabular}

(continued on next page)
Delinquency and criminal behavior, illicit drug use, teen pregnancy, tobacco, violence. 


\begin{tabular}{|llll|}
\hline $\begin{array}{l}\text { Table 2 } \\
\text { (continued) }\end{array}$ & & \\
Program & Description & Rating & Impact \\
\hline $\begin{array}{c}\text { Big Brothers Big } \\
\text { Sisters of } \\
\text { America }\end{array}$ & $\begin{array}{c}\text { Selective prevention for ages 5-18 (community setting). } \\
\text { Program matching adult mentors with an at-risk child to } \\
\text { develop a caring and supportive relationship over 12 mo. }\end{array}$ & $\begin{array}{c}\text { Promising } \\
\text { Cost Per } \\
\text { Individual }\end{array}$ & $\begin{array}{l}\text { Alcohol, antisocial aggressive } \\
\text { behavior, close relationships } \\
\text { with parents, close relationships } \\
\text { with peers, illicit drug use, } \\
\text { prosocial behavior, truancy and } \\
\text { school attendance. }\end{array}$ \\
\hline Keep Safe & $\begin{array}{l}\text { Selective prevention for ages 12-14 (community setting). Six- } \\
\text { session group-based intervention for the foster-care youth } \\
\text { and a 6-session, group-based intervention for the foster } \\
\text { parents, focusing on goal setting, positive relationships, } \\
\text { decision making, stability at home, and behavioral } \\
\text { reinforcement techniques. }\end{array}$ & $\begin{array}{c}\text { Pllicit drug use, prosocial behavior, } \\
\text { sexual risk behaviors, tobacco. }\end{array}$ \\
\hline
\end{tabular}

N/A, not applicable; STI, sexually transmitted infections.

Adapted from University of Colorado Boulder Institute of Behavioral Science, Center for the Study and Prevention of Violence. Blueprints for Healthy Youth Development. Available at: http://www.blueprintsprograms.com/programs. Accessed July 25, 2015; with permission. 
Sisters. ${ }^{97,98}$ Communities That Care ${ }^{99}$ is an example of a tested, effective communitylevel strategic approach to creating prevention infrastructure by building community coalition capacity to assess and prioritize risk, protection, and problems among their youth through school surveys; choosing effective prevention programs that match their priorities; and implementing chosen programs with fidelity. Communities That Care also provides tools for ongoing evaluation of the programs' effectiveness so that communities can track progress and make adjustments when needed, and explores funding mechanisms to sustain prevention efforts. In a randomized trial, researchers found that communities using the approach were able to reduce alcohol and tobacco use by approximately a third and delinquency by $25 \% .^{100,101}$ Results have been largely replicated in a quasi-experimental statewide study in Pennsylvania. ${ }^{102}$

\section{Challenges in Prevention}

Unfortunately, and too often, American society's response to major problems has been reactive. Such responses have evolved out of understandable efforts to deal with problems once they have emerged. The systems to deliver treatment interventions are quite developed for most of the common and costly substance use and allied psychological disorders once these problems have developed. Each year, more than 6 million young people receive treatment for mental, emotional, or behavioral problems. The financial costs of treatment services and lost productivity attributed to the related behavioral health problems of depression, conduct disorder, and substance abuse are estimated at $\$ 247$ billion per year. ${ }^{16}$ These costs are for a system that reaches only a small portion of those in need of treatment. Although treatment of existing problems is a critical service, evidence from more than 40 years of research suggests that we can prevent substance abuse and other problems from developing in the first place, and that disseminating proven prevention programs is likely to have substantial impact on rates of disorder and related harm. Given the number of tested, effective prevention programs, a population-wide reduction in substance use and negative consequences of substance use is possible. A recent discussion paper ${ }^{103}$ published by the National Academy of Medicine suggested the following.

Universal prevention has the potential to reach those who are not directly involved in the formal health and social service delivery sectors. Simultaneously ensuring that preventive interventions reach the highest-risk children and youth, who will benefit disproportionately from these efforts, will promote health equity. Preventing problems before they occur reduces human suffering and preempts costly punitive responses to these problems from education, law enforcement, child welfare, mental health, or juvenile justice systems. It is imperative that strategies to bring preventive interventions to scale pursue these dual objectives of overall population health and health equity for the most vulnerable and underserved populations (p. 10).

The challenge is how to get prevention programs widely implemented in communities. Despite the promise, a number of challenges arise in scaling up proven prevention programs. Given that services are organized and delivered by separate organizations (health care, public health, education, substance abuse, mental health, juvenile justice, and child welfare), community prevention coalitions are needed to bring together professionals, information, and funding to create teamwork and cooperation across different community sectors. Additionally, communities are different from one another, and it is unlikely that any one approach will provide the largest impact across communities. 
To pick the best prevention programs for a given community, data need to be collected identifying the risk and protective factors of greatest importance to the youth living in each community. Because multiple risk factors for adolescent substance use and other problems have been identified in multiple socialization domains, there is need for efficient measurement. Researchers are now able to evaluate the presence of multiple risk factors with succinct questionnaires that produce valid and reliable results. ${ }^{13}$ Such comprehensive surveys can be used to prioritize those risk factors that are most elevated or depressed and protective factors that are most depressed. Finally, evidence-based prevention programs will need sustainable funding, meaning cooperation across multiple agencies. Resnick and colleagues ${ }^{104}$ suggest moving $10 \%$ of the total funds dedicated to children to efficacious prevention programs and policies.

\section{FUTURE DIRECTIONS FOR PREVENTION SCIENCE}

Much progress has been completed in recent decades to improve the evidence base of prevention programs for substance use, including the identification and measurement of risk and protective factors, the development and testing of prevention programs, and recent work on testing prevention infrastructure. There is much work still to be done. Service systems addressing substance use focus mainly on intervention once substance use has become a problem; there are few resources dedicated to community-wide prevention programs, despite the growing support for these programs. To increase prevention funding, government officials, professionals, and the public should be educated about the evidence and cost effectiveness of prevention programs. Databases (such as the Blueprints database) should be expanded to include as many tested, effective prevention programs and policies as possible; consolidating research in easy-to-use tools can enhance the public's ability to choose efficacious programs when seeking to address substance use problems locally. Also, studies addressing the implementation and dissemination challenges of prevention programs would help to inform researchers and community organizers about the challenges of going to scale and creating sustainable change. Similarly, translational research on adaptation to unique needs of underserved or marginalized populations would significantly augment the research base and assist with promoting health equity. ${ }^{102}$ Although research has demonstrated that risk factors are often common across national and racial boundaries, adaptations in program curriculum may assist with better fit and acceptability by different cultures; this could increase the cultural competence of prevention interventions and simultaneously expand intervention reach and impact. The development and growth of prevention coalitions may be an ideal place to further prevention science, as they offer local, place-specific knowledge that can enhance intervention effectiveness. ${ }^{105}$ Finally, efforts to develop more prevention interventions specific to emerging adulthood should be pursued. Presently, Blueprints cites only 2 interventions that have demonstrated adequate empirical effectiveness on substance use for this population. ${ }^{81}$ Given that substance use and its related problems peak during this time period, ${ }^{56,57}$ additional prevention programs targeting young adult outcomes should be prioritized.

We end with a quote from a commentary from the National Academy of Medicine: "Prevention is the best investment we can make in behavioral health-and the time to make it is now." $103(\mathrm{p} 20)$

\section{REFERENCES}

1. Holmbeck GN. A developmental perspective on adolescent health and illness: an introduction to the special issues. J Pediatr Psychol 2002;27(5):409-16. 
2. Feldman SS, Elliott GR. At the threshold: the developing adolescent. Cambridge (MA): Harvard University Press; 1990.

3. Valencia LS, Cromer BA. Sexual activity and other high-risk behaviors in adolescents with chronic illness: a review. J Pediatr Adolesc Gynecol 2000;13(2): 53-64.

4. White AM. Understanding adolescent brain development and its implications for the clinician. Adolesc Med 2009;20(1):73-90.

5. Jessor R. Risk behavior in adolescence: a psychosocial framework for understanding and action. J Adolesc Health 1991;12(8):597-605.

6. Patton GC, Coffey C, Sawyer SM, et al. Global patterns of mortality in young people: a systematic analysis of population health data. Lancet 2009; 374(9693):881-92.

7. Steinberg LD. Age of opportunity: lessons from the new science of adolescence. Boston: Houghton Mifflin Harcourt; 2014.

8. Snow WH, Gilchrist LD, Schinke SP. A critique of progress in adolescent smoking prevention. Child Youth Serv Rev 1985;7(1):1-19.

9. Flay BR, Brannon BR, Johnson CA, et al. The television school and family smoking prevention and cessation project. I. Theoretical basis and program development. Prev Med 1988;17(5):585-607.

10. Ennett ST, Tobler NS, Ringwalt CL, et al. How effective is drug abuse resistance education? A meta-analysis of project DARE outcome evaluations. Am J Public Health 1994;84(9):1394-401.

11. Thomas BH, Mitchell A, Devlin MC, et al. Small group sex education at school: the McMaster Teen Program. In: Miller BC, Card JJ, Paikoff RL, et al, editors. Preventing adolescent pregnancy: model programs and evaluations. Sage focus editions, vol. 140. Thousand Oaks (CA): Sage; 1992. p. 28-52.

12. Ellickson PL, Bell RM. Drug prevention in junior high: a multi-site longitudinal test. Science 1990;247(4948):1299-305.

13. Catalano RF, Fagan AA, Gavin LE, et al. Worldwide application of prevention science in adolescent health. Lancet 2012;379(9826):1653-64.

14. Coie JD, Watt NF, West SG, et al. The science of prevention: a conceptual framework and some directions for a national research program. Am Psychol 1993; 48(10): 1013-22.

15. Hawkins JD, Catalano RF, Miller JY. Risk and protective factors for alcohol and other drug problems in adolescence and early adulthood: implications for substance abuse prevention. Psychol Bull 1992;112(1):64-105.

16. O'Connell ME, Boat T, Warner KE, editors. Preventing mental, emotional, and behavioral disorders among young people: progress and possibilities. Washington, DC: National Academies Press; 2009.

17. Fergusson DM, Horwood LJ. Resilience to childhood adversity: results of a 21 year study. In: Luthar SS, editor. Resilience and vulnerability: adaptation in the context of childhood adversities. New York: Cambridge University Press; 2003. p. 130-55.

18. Rose G. Sick individuals and sick populations. Int J Epidemiol 2001;30(3): 427-32.

19. Catalano RF, Haggerty KP, Hawkins JD, et al. Prevention of substance use and substance use disorders: the role of risk and protective factors. In: Kaminer $Y$, Winters KC, editors. Clinical manual of adolescent substance abuse treatment. Washington, DC: American Psychiatric Publishing; 2011. p. 25-63. 
20. Glaser RR, Horn MLV, Arthur MW, et al. Measurement properties of the Communities That Care ${ }^{\circledR}$ Youth Survey across demographic groups. J Quant Criminol 2005;21(1):73-102.

21. Stone AL, Becker LG, Huber AM, et al. Review of risk and protective factors of substance use and problem use in emerging adulthood. Addict Behav 2012; 37(7):747-75.

22. Duncan SC, Duncan TE, Strycker LA. A multilevel analysis of neighborhood context and youth alcohol and drug problems. Prev Sci 2002;3(2):125-33.

23. Maddahian E, Newcomb MD, Bentler PM. Risk factors for substance use: ethnic differences among adolescents. J Subst Abuse 1988;1(1):11-23.

24. Wills TA, Sargent JD, Gibbons FX, et al. Movie exposure to alcohol cues and adolescent alcohol problems: a longitudinal analysis in a national sample. Psychol Addict Behav 2009;23(1):23-35.

25. Sampson RJ, Lauritsen JL. Violent victimization and offending: individual, situational, and community level risk factors. In: Reiss Albert J Jr, Roth JA, editors. Understanding and preventing violence: vol. 3. Social influences. Washington, DC: National Academy Press; 1994. p. 1-114.

26. Elliott DS, Wilson WJ, Huizinga D, et al. The effects of neighborhood disadvantage on adolescent development. J Res Crime Deling 1996;33(4):389-426.

27. Najaka SS, Gottfredson DC, Wilson DB. A meta-analytic inquiry into the relationship between selected risk factors and problem behavior. Prev Sci 2001;2(4): $257-71$.

28. Kosterman R, Hawkins JD, Guo J, et al. The dynamics of alcohol and marijuana initiation: patterns and predictors of first use in adolescence. Am J Public Health 2000;90(3):360-6.

29. Peterson PL, Hawkins JD, Abbott RD, et al. Disentangling the effects of parental drinking, family management, and parental alcohol norms on current drinking by black and white adolescents. J Res Adolesc 1994;4(2):203-27.

30. Barnes GM, Welte JW. Patterns and predictors of alcohol use among 7-12th grade students in New York State. J Stud Alcohol 1986;47(1):53-62.

31. Haggerty KP, Skinner ML, MacKenzie EP, et al. A randomized trial of Parents Who Care: effects on key outcomes at 24-month follow-up. Prev Sci 2007; 8(4):249-60.

32. Pagan JL, Rose RJ, Viken RJ, et al. Genetic and environmental influences on stages of alcohol use across adolescence and into young adulthood. Behav Genet 2006;36(4):483-97.

33. Bierut LJ, Dinwiddie SH, Begleiter $\mathrm{H}$, et al. Familial transmission of substance dependence: alcohol, marijuana, cocaine, and habitual smoking: a report from the Collaborative Study on the Genetics of Alcoholism. Arch Gen Psychiatry 1998;55(11):982-8.

34. Kendler KS, Prescott CA, Myers J, et al. The structure of genetic and environmental risk factors for common psychiatric and substance use disorders in men and women. Arch Gen Psychiatry 2003;60(9):929-37.

35. Agrawal A, Lynskey MT. The genetic epidemiology of cannabis use, abuse and dependence. Addiction 2006;101(6):801-12.

36. McGue M, Elkins I, lacono WG. Genetic and environmental influences on adolescent substance use and abuse. Am J Med Genet 2000;96(5):671-7.

37. Brewer DD, Hawkins JD, Catalano RF, et al. Preventing serious, violent, and chronic juvenile offending: a review of evaluations of selected strategies in childhood, adolescence, and the community. In: Howell JC, Krisberg B, Hawkins JD, 
et al, editors. A sourcebook: serious, violent, and chronic juvenile offenders. Thousand Oaks (CA): Sage; 1995. p. 61-141.

38. Patterson GR, Dishion TJ. Contributions of families and peers to delinquency. Criminology 1985;23(1):63-79.

39. Maggs JL, Patrick ME, Feinstein L. Childhood and adolescent predictors of alcohol use and problems in adolescence and adulthood in the National Child Development Study. Addiction 2008;103(Suppl 1):7-22.

40. King KM, Chassin L. Adolescent stressors, psychopathology, and young adult substance dependence: a prospective study. J Stud Alcohol Drugs 2008; 69(5):629-38.

41. Englund MM, Egeland B, Oliva EM, et al. Childhood and adolescent predictors of heavy drinking and alcohol use disorders in early adulthood: a longitudinal developmental analysis. Addiction 2008;103(Suppl 1):23-35.

42. Sher KJ, Walitzer KS, Wood PK, et al. Characteristics of children of alcoholics: putative risk factors, substance use and abuse, and psychopathology. J Abnorm Psychol 1991;100(4):427-48.

43. Zucker RA. Anticipating problem alcohol use developmentally from childhood into middle adulthood: what have we learned? Addiction 2008;103(Suppl 1): $100-8$.

44. Elliott DS, Huizinga D, Ageton SS. Explaining delinquency and drug use. Beverly Hills (CA): Sage; 1985.

45. Oxford ML, Harachi TW, Catalano RF, et al. Preadolescent predictors of substance initiation: a test of both the direct and mediated effect of family social control factors on deviant peer associations and substance initiation. Am J Drug Alcohol Abuse 2001;27(4):599.

46. Beyers JM, Toumbourou JW, Catalano RF, et al. A cross-national comparison of risk and protective factors for adolescent substance use: the United States and Australia. J Adolesc Health 2004;35(1):3-16.

47. Arthur MW, Hawkins JD, Pollard JA, et al. Measuring risk and protective factors for substance use, delinquency, and other adolescent problem behaviors: The Communities That Care Youth Survey. Eval Rev 2002;26(6):575-601.

48. Robins LN, Przybeck TR. Age of onset of drug use as a factor in drug and other disorders. In: Jones CL, Battjes RJ, editors. Etiology of drug abuse: implications for prevention (NIDA Research Monograph No. 56). Rockville (MD): National Institute on Drug Abuse; 1985. p. 178-92.

49. Arnett $\mathrm{J} J$. Emerging adulthood. A theory of development from the late teens through the twenties. Am Psychol 2000;55(5):469-80.

50. George LK. Sociological perspectives on life transitions. Annu Rev Sociol 1993; 19:353-73.

51. Hogan DP, Astone NM. The transition to adulthood. Annu Rev Sociol 1986;12: 109-30.

52. Shanahan MJ. Pathways to adulthood in changing societies: variability and mechanisms in life course perspective. Annu Rev Sociol 2000;26:667-92.

53. Osgood DW. On your own without a net: the transition to adulthood for vulnerable populations. Chicago: University of Chicago Press; 2005.

54. Schulenberg JE, Maggs JL. A developmental perspective on alcohol use and heavy drinking during adolescence and the transition to young adulthood. J Stud Alcohol 2002; Suppl 14:54-70.

55. Schulenberg JE, Sameroff AJ, Cicchetti D. The transition to adulthood as a critical juncture in the course of psychopathology and mental health. Dev Psychopathol 2004;16(4):799-806. 
56. Park MJ, Mulye TP, Adams SH, et al. The health status of young adults in the United States. J Adolesc Health 2006;39(3):305-17.

57. Substance Abuse and Mental Health Services Administration. Results from the 2012 National Survey on Drug Use and Health: summary of national findings, NSDUH series H-46, HHS publication No. (SMA) 13-4795. Rockville (MD): Substance Abuse and Mental Health Services Administration; 2013.

58. National Institute on Alcohol Abuse and Alcoholism. Five year strategic plan fy07-11. Bethesda (MD): National Institute on Alcohol Abuse and Alcoholism; 2006.

59. Prejean J, Song R, An Q, et al. Subpopulation estimates from the HIV incidence surveillance system-United States, 2006. MMWR Morb Mortal Wkly Rep 2008; 57(36):985-9.

60. Johnston LD, O'Malley PM, Bachman JG, et al. Monitoring the Future national survey results on drug use, 1975-2007. Volume II: college students and adults age 19-50 (NICH Publication No. 09-7403). Bethesda (MD): National Institute on Drug Abuse; 2009.

61. Jackson KM, Sher KJ, Schulenberg JE. Conjoint developmental trajectories of young adult alcohol and tobacco use. J Abnorm Psychol 2005;114(4):612-26.

62. Gmel G, Rehm J, Room R, et al. Dimensions of alcohol-related social and health consequences in survey research. J Subst Abuse 2000;12(1-2):113-38.

63. Hingson R, Winter M. Epidemiology and consequences of drinking and driving. Alcohol Res Health 2003;27(1):63-78.

64. Leonard KE, Roberts LJ. Alcohol in the early years of marriage. Alcohol Health Res World 1996;20(3):192-6.

65. Roman PM, Johnson JA. Alcohol's role in work-force entry and retirement. Alcohol Health Res World 1996;20(3):162-9.

66. Quigley LA, Marlatt GA. Drinking among young adults: prevalence, patterns, and consequences. Alcohol Health Res World 1996;20(3):185-91.

67. White HR, McMorris BJ, Catalano RF, et al. Increases in alcohol and marijuana use during the transition out of high school into emerging adulthood: the effects of leaving home, going to college, and high school protective factors. J Stud Alcohol 2006;67(6):810-22.

68. Ichiyama MA, Fairlie AM, Wood MD, et al. A randomized trial of a parent-based intervention on drinking behavior among incoming college freshmen. J Stud Alcohol Drugs 2009;16(16):67-76.

69. Mason WA, Kosterman R, Haggerty KP, et al. Gender moderation and social developmental mediation of the effect of a family-focused substance use preventive intervention on young adult alcohol abuse. Addict Behav 2009; 34(6-7):599-605.

70. Presley CA, Meilman PW, Leichliter JS. College factors that influence drinking. J Stud Alcohol 2002;Suppl 14:82-90.

71. White HR, Jackson K. Social and psychological influences on emerging adult drinking behavior. Alcohol Res Health 2004/2005;28(4):182-90.

72. Duncan GJ, Wilkerson B, England P. Cleaning up their act: the effects of marriage and cohabitation on licit and illicit drug use. Demography 2006;43(4): 691-710.

73. Oesterle S, Hill KG, Hawkins JD, et al. Positive functioning and alcohol-use disorders from adolescence to young adulthood. J Stud Alcohol Drugs 2008;69(1): 100-11.

74. Casswell S, Pledger M, Hooper R. Socioeconomic status and drinking patterns in young adults. Addiction 2003;98(5):601-10. 
75. Resnick MD, Bearman PS, Blum RW, et al. Protecting adolescents from harm. Findings from the National Longitudinal Study on Adolescent Health. JAMA 1997;278(10):823-32.

76. Mrazek PJ, Haggerty RJ, Committee on Prevention of Mental Disorders, Institute of Medicine, editors. Reducing risks for mental disorders: frontiers for prevention intervention research. Washington, DC: National Academy Press; 1994.

77. Bandura A. Social foundations of thought and action: a social cognitive theory. Englewood Cliffs (NJ): Prentice-Hall; 1986.

78. Hawkins JD. Science, social work, prevention: finding the intersections. Soc Work Res 2006;30(3):137-52.

79. Becker $\mathrm{MH}$. The health belief model and personal health behavior. Thorofare (NJ): C.B. Slack; 1974.

80. McGorry PD, Purcell R, Goldstone S, et al. Age of onset and timing of treatment for mental and substance use disorders: implications for preventive intervention strategies and models of care. Curr Opin Psychiatry 2011;24(4):301-6.

81. Center for the Study and Prevention of Violence. Blueprints for Healthy Youth Development. 2015. Available at: http://www.blueprintsprograms.com/. Accessed August 3, 2015.

82. SAHMSA. NREPP: SAHMSA's National Registry of Evidence-Based Programs and Practices. 2015. Available at: http://www.nrepp.samhsa.gov/. Accessed August 23, 2015.

83. Office of Juvenile Justice and Delinquency Prevention. Model programs guide. Available at: http://www.ojjdp.gov/mpg/. Accessed August 23, 2015.

84. Institute of Education Sciences. What works clearinghouse. Available at: http:// ies.ed.gov/ncee/wwc/. Accessed August 23, 2015.

85. Centers for Disease Control and Prevention. The guide to community preventive services: The Community Guide: what works to promote health. 2015. Available at: http://www.thecommunityguide.org/. Accessed August 23, 2015.

86. Coalition for Evidence-Based Policy. Coalition for Evidence-Based Policy. 2015. Available at: http://coalition4evidence.org/. Accessed August 23, 2015.

87. Flay B, Allred C, Ordway N. Effects of the Positive Action program on achievement and discipline: two matched-control comparisons. Prev Sci 2001;2(2): 71-89.

88. Dimeff LA. Brief Alcohol Screening and Intervention for College Students (BASICS): a harm reduction approach. New York: Guilford Press; 1999.

89. Botvin G, Griffin K. Life Skills Training: empirical findings and future directions. J Prim Prev 2004;25(2):211-32.

90. Park J, Kosterman R, Hawkins JD, et al. Effects of the "Preparing for the Drug Free Years" curriculum on growth in alcohol use and risk for alcohol use in early adolescence. Prev Sci 2000;1(3):125-38.

91. Mason WA, Kosterman R, Hawkins JD, et al. Reducing adolescents' growth in substance use and delinquency: randomized trial effects of a preventive parent-training intervention. Prev Sci 2003;4(3):203-312.

92. Prado G, Pantin H, Briones E, et al. A randomized controlled trial of a parentcentered intervention in preventing substance use and HIV risk behaviors in Hispanic adolescents. J Consult Clin Psychol 2007;75(6):914-26.

93. Kumpfer KL, Whiteside HO, Greene JA, et al. Effectiveness outcomes of four age versions of the Strengthening Families Program in statewide field sites. Group Dyn 2010;14(3):211-29. 
94. Spoth R, Redmond C, Shin C, et al. Substance-use outcomes at 18 months past baseline: the PROSPER Community-University Partnership Trial. Am J Prev Med 2007;32(5):395-402.

95. Barton C, Alexander J, Waldron H, et al. Generalizing treatment effects of Functional Family Therapy: three replications. Am J Fam Ther 1985;13(3):16-26.

96. Wechsler H, Nelson TE, Lee JE, et al. Perception and reality: a national evaluation of social norms marketing interventions to reduce college students' heavy alcohol use. J Stud Alcohol 2003;64(4):484-94.

97. Tierney JP, Grossman JB, Resch NL. Making a difference: an impact study of Big Brothers Big Sisters. Philadelphia: Public/Private Ventures; 1995.

98. Herrera C, Grossman JB, Kauh TJ, et al. Mentoring in schools: an impact study of Big Brothers Big Sisters school-based mentoring. Child Dev 2011;82(1): 346-61.

99. Hawkins JD, Catalano RF Jr. Communities That Care: action for drug abuse prevention. 1st edition. San Francisco (CA): Jossey-Bass; 1992.

100. Hawkins JD, Oesterle S, Brown EC, et al. Results of a type 2 translational research trial to prevent adolescent drug use and delinquency: a test of Communities That Care. Arch Pediatr Adolesc Med 2009;163(9):789-98.

101. Hawkins JD, Oesterle S, Brown EC, et al. Youth problem behaviors 8 years after implementing the Communities That Care prevention system. A communityrandomized trial. JAMA Pediatr 2014;168(2):122-9.

102. Feinberg ME, Jones D, Greenberg MT, et al. Effects of the Communities That Care model in Pennsylvania on change in adolescent risk and problem behaviors. Prev Sci 2010;11(2):163-71.

103. Hawkins JD, Jenson JM, Catalano R, et al. Unleashing the power of prevention (Discussion Paper). Washington, DC: Institute of Medicine and National Research Council; 2015. Available at: http://nam.edu/wp-content/uploads/ 2015/06/DPPowerofPrevention.pdf.

104. Resnick MD, Catalano RF, Sawyer SM, et al. Seizing the opportunities of adolescent health. Lancet 2012;379(9826):1564-7.

105. Fagan AA, Hawkins JD, Catalano RF. Engaging communities to prevent underage drinking. Alcohol Res Health 2011;34(2):167-74. 